\title{
In memory of Eric Archimbaud
}

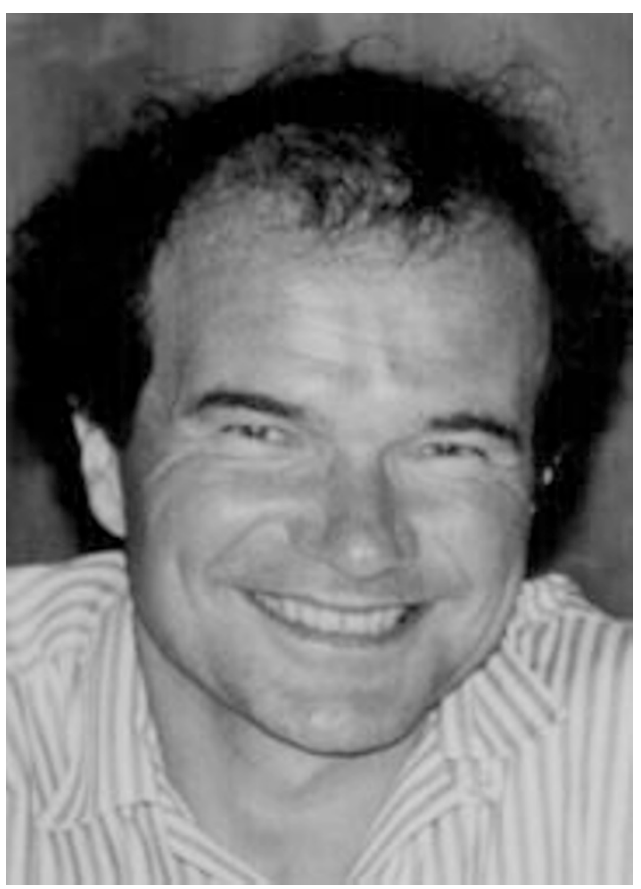

Eric Jean Noël Archimbaud was born on 20 December 1954 in Lyon, France. He followed his father's profession and became a doctor. He married Soledad Delgado by whom he had two sons and one daughter. After obtaining his medical degree Eric Archimbaud spent 1 year attached to the Leukemia Service directed by Dr Harvey Preisler at the Roswell Park Memorial Institute in Buffalo, New York. He then returned to Lyon as Assistant Professor at the Claude Bernard University in Lyon, where he obtained his PhD. Subsequently, he was promoted to full Professor of Hematology. His special interests were the investigation and treatment of acute myeloid leukemia and myelodysplasia. He made major contributions to clinical and fundamental research in stem cell transplantion for leukemia and was a prominent member of the European Group for Blood and Marrow Transplantation. He participated in more than 20 collaborative trials involving mainly acute myeloid leukemia and myelodysplastic syndromes. He was the author of more than 100 articles published in peer-reviewed journals and he had given more than 200 presentations in scientific meetings. He was a member of numerous scientific societies including the Société Française de Greffe de Moelle, the American Society of Hematology, the International Society of Hematology and the American Association for Cancer Research. In 1997 he organized the 26th Annual Meeting of the International Society for Experimental Hematology in Cannes, judged by many to be one of the ISEH's most successful and enjoyable meetings. At the time of his death he was Associate Chief of the Department of Hematology in the Hôpital Edouard Herriot in Lyon.

Eric Archimbaud died in a tragic accident on 25 March 1998 at the age of 43 . He combined true sensitivity with a charming personality. He was very greatly admired by all who worked with him and importantly also by his many patients. He was able to create a team spirit based on welldefined common objectives which all members of his team now want, in his memory, to maintain and augment in the future.

Mauricette Michallet and Denis Fiere Lyon, France 